while they are establishing their reputations and building up their experience. The first of the colleges to assume university status will bo the University College of Khartoum, which has announced its decision to seek degree-granting authority in the present acarlemical year. There is no uniform scheme for' special relationship with the University of London and it is developed separately for each college, tho college working out in consultation with the University of London the arrangements which best suit its particular local conditions. For example, if the development of secondary schools in a particular territory makes desirable that a minimum entrance requirement to the university college should be adopted which is lower than that obtaining in the United Kingdom, the college and the University of London can agree to accept a modified standard of admission. If a lower standard of entrance examination is instituted, the length of the degree course is normally extended by one academical year. Special relationship involves the arrangement that members of the staffs of the university college take part in the setting and marking of the examinations for their own students, with examiners from the University of London. Furthermore, full-time members of the teaching and research staffs of the colleges in special relationship with the University of London may, if appropriately qualified, register as internal students for the London Ph.D. degree, and continue to carry out their research work in the university college.

The Inter-University Council itself meets four times in each academical year, and annually appoints an executive committee which usually meets monthly during each session. Each of the universities in the United Kingdom, together with the three Colonial universities, appoints a representative member. Recently university colleges in England have also appointed representatives, while the Council has co-opted additional members in their individual capacities. The educational advisor to the Secretary of State for the Colonies, Sir Christopher Cox, has served ex officio. The late Sir James Irvine was the first chairman of the Council and served until February 1951, when he was followed as chairman by Sir Alexander Carr-Saunders, who had until then been vice-chairman. Sir Raymond Priestley then succeeded Sir Alexander as vice-chairman. The secretary has until recently been Dr. Walter Adams, who left in May 1955 to sucseed Dr. W. Rollo as principal of the University College of Rhodesia and Nyasaland. He was succoeded in the office of secretary by S. J. Worsley. By overlapping membership and by other means, the Council has maintained close co-operation with the Advisory Committee on the Colonial Colleges of Arts, Science and Technology, with the Advisory Committee on Education in the
Colonies, with the Colonial Research Council and with the various advisory research councils and com. mittees of the Colonial Office. It has worked in very close association with the University of London Senate Committee on Colleges Overseas in Special Relationship. 'The Council is represented by two members of the Colonial University Grants Advisory Committeo. The cost of the Council's secretariat, office accommodation, visits and advertising of vacancies has been met by an annual grant from the Colonial Office.

The Council has attached great importance to the visits which its members and other representatives have been enabled to make to the overseas universities and colleges, and indeed its work would not have been possible without them. Air transport, which has developed so much since the War, has made possible the close personal contacts between the overseas and the home universities, the visits of experts and examiners, the frequent leave of academic staff, and the rapid exchange of correspondence and examination papers. The post-war period has also fortunately coincided with economic prosperity in almost all the overseas territories, and with the growth of responsible nationalism and the acceptance by both Great Britain and the dependent territories of a policy of transference of power to which the development of universities is well attuned. The University Grants Committee in the United Kingdom has said that "the dependence of the Universities on the State is balanced by a dependence of the State on the Universities". This mutual dependence and partnership is as clear in the Colonies as it is at home. The prestige of university institutions as a whole has never been higher, and they are exceptionally responsible to their national and international obligations.

In the future, as in the past, the overseas universities and colleges will look for co-operation to the universities of the United Kingdom. Although the University of London has been enabled, by its special position, to give more help than other universities in Britain, one may hope that the other universities will not fail to take as much interest in the overseas institutions as circumstances will make possible. One way in which they can help is by assisting the promising graduates of the Colonial university institutions to come to Great Britain for postgraduate and further specialist studies. The need for finances for the provision of postgraduate fellow. ships is clear. It is to be hoped that all will help who wish to see the development of universities in the British Commonwealth go forward in a manner which is worthy of the name which the Commonwealth has itself won in world affairs.

$$
\text { F. G. Young }
$$

\title{
ZOONOSES IN EAST AFRICA
}

$\mathrm{T}$ THE annual scientific conference organized by the East African Medical Research Scientific Advisory Committee was held in the Makerere College Medical School, Kampala, Uganda, during January 11-13. Some eighty delegates came from East African torritories, and visitors from Britain, Egypt, Israel and South Africa joined in the discussions. In opening the conference, the Governor of Uganda spoke of the dependence of East Africa upon Great
Britain and the United States of America for basic long-term research and on support for such research, and this was well illustrated in many of the discussions, particularly in relation to taxonomic research.

Dr. H. Hoogstraal, of the U.S. Naval Medical Research Unit, Cairo, described the great faunal explorations which the Unit has carried out in northeastern Africa as a basic preliminary to ecological 
studies. This immense collection of mammals, birds, reptiles, amphibians and ectoparasites is now undergoing detailed examination, and much new information is emerging and will be made available in keys and check lists. Much admiration was expressed by conference members of this study; it is not being carried out under the pressure of a disease outbreak, in which circumstances hasty and inaccurate conceptions can arise ; and it is regrettable that in East Africa so little collecting is being done. The need for a basic faunal study unit is great, there aro serious gaps in existing collections and many taxonomic concepts require stabilizing. It is difficult to get bird, mammal or insect identifications done in East Africa, and the resources of the British Museum are frequently called upon. But there are limits to these resources and frequent delays in identifications, despite the willing help of the Museum staff, who have many other calls upon their services.

The difficulties and expensiveness of faunal research studies in Fast Africa were clearly recognized, and Dr. Hoogstraal stoutly maintained that the situation is not so gloomy as some have pictured. The British aro notable collectors and senders-home of material, the British Museum's resources are immense and can be supplemented and more and better keys can be provided.

Nevertheless, the lack of basic East African data makes research upon the local zoonoses difficult, as was shown in symposia on rabies, $Q$ fever, brucellosis, helminthiasis, virus zoonoses and trypanosomiasis. The status of trypanosomiasis as a zoonosis is not at present established, and the conference heard of new efforts being made in the crucial experiment of isolating Trypanosoma rhodesiense from wild animals. Dr. K. C. Willett spoke of several lines of investi. gation which suggest the possibility that $T r$. rhodesiense may have developed from Tr. brucei, the game trypanosome which is non-infective for humans, by repeated passages through Glossina pallipedes, and this possibility is being investigated. The conference warmly welcomed the presence of $\mathrm{Dr}$. B. Weitz, of the Lister Institute, whose studies of the blond meals of tsetse fly and other arthropods are so important to East Africa. If the hosts of tsetse fly could be clearly identified, specific measures of eradication could be devised and the distasteful method of wholesale game slaughter discontinued. Thus Dr. Weitz mentioned that he has never found the blood of certain common game animals in tsetse fly. The policy of wholesale game slaughter found no support in the conference, and this for two reasons. First, because of the promises held out by further work on the lines Dr. Woitz had indicated, which would, it was hoped, advance rapidly ; and secondly, because of the general realization that until population pressure rises to the point where there is it real need for the land now occupied by tsetse, there is not likely to be any major decrease in the size of such areas. There is, therefore, no point in adopting such an unpleasant and unnecessary policy in East Africa.

Dr. R. B. Heisch pleaded for a holistic synecological approach to tho problem of East African zoonoses, on a basis of detailed taxonomic studies and investigations of the host-parasite relationships. This approach has been utilized in existing studies of plague, relapsing fever and kala azar in East Africa. Dr. Heisch believes that the more resistant animal hosts may be important in maintaining the disease organisms, though this is scarcely the case in the virus zoonoses, where a continuous supply of nonimmunes, who circulate the virus in the blood in large amounts, is an essential to maintaining a zoonosis. Moreover, when a zoonosis gets under way, man-to-man contact may be sufficient to keep the infection spreading, and in Kenya the kala azar epidemic may be spreading in this way. But Dr. Heisch's conception is worthy of serious study; man's fellow sufferers are too often regarded as his enemies. The snail, that humble but useful member of the aquatic community, as Mr. R. Beauchamp called it, is the chief sufferer from schistosomiasis. The resistant animal hosts of a zoonosis must not be too readily dismissed.

Much more information is needed, too, about the small mammals of East Africa, which may be involved in a number of zoonoses, and co-operation is most desirable between those who trap mammals for a variety of purposes. As much serum as possible should be collected, and a plea was made for the setting up of a 'museum' of deep-frozen sera from mammals, as this would greatly expedite the serological investigations of zoonoses. Detailed synecological studies might explain some of the discontinuities in disease incidence in East Africa which cannot at present be explained. Thus rift-valley fever antibodies are present in sera of cattle in both the Eastern and Western Rift valleys, though they are not found in sera from the higher intervening areas in Uganda. Knowledge is too scanty at present to explain these discontinuities, but in this connexion much attention is being paid to birds as possible disease vectors. Dr. R. M. Taylor described the major part they are believed to play in the endemiology and epidemiology of West Nile virus infections in Egypt and in Israel. The breeding seasons can provide a fresh stock of non-immunes, and in their breeding areas some virus infections may be endemic. In the areas to which, or through which, such birds migrate, epizootics and outbreaks of zoonotic diseases may occur. Unusual climatic conditions may delay, alter or extend these areas, leading to mysterious outbreaks of disease in areas previously unaffected or only affected at long intervals. These possibilities in relation to a number of virus zoonoses are now being investigated, and they may be of importance in such an epizootic disease as African horse sickness. There are periodic outbreaks of this disease in widely separate geographical areas after intervals of freedom, which may extend to ten or twelve years.

But in searching for explanations of these and other zoonotic outbreaks, there are limitations in the taxonomic approach which should be borne in mind. Thus Dr. A. Haddow pointed out that the fact that the same species exists in two different areas is no guarantee that it behaves identically in both places. In one place Aedes simpsoni will bite man freely, whereas as little as ten miles away it will only bite animals. Some anopheline species feed exclusively by day in some areas, exclusively by night in other areas. There is, in a sense, no end to these studies. Moreover, a parasite introduced into a new area may adapt itself to previously resistant local vectors. Dr. M. Davies quoted examples of this from Israel in relation to schistosomiasis, introduced by immigrants from Iraq, and filariasis introduced from Cochin. Therefore, on a basis of sound taxonomy, each zoonosis requires specific ecological study in each affected area. Lack of appreciation of this has led to much wasted effort in trying to apply control measures, devised upon a basis of experience else- 
where, to a specifically local problem. 'Thus in Kenya, night screening of cattle from mosquitoes protects them from Rift Valley fever, whereas in South Africa the vectors are day-biting mosquitoes.

If each local problem requires specific study, then it is important to start in the most promising areas. In East Africa, the forest fringes are such areas. There the species of the forest and the open country come in contact, and there are other species which can only maintain themselves on the forest fringes. But this is only one such 'fringe area'; in Kenya, kala azar is somehow connected with the termite hills which represent another such contact area. Several speakers stressed our ignorance of forest animal ecology and hoped that more work would be done in this field. Others directed attention to the effect of turning pasture land into arable land, and to the effects of new irrigation schemes in East Africa.

One curious feature of the conference was the repeated criticism of the laws of the East African territories. It was pointed out that existing legislation in many fields is extremely advanced and ridiculously at variance with existing practice. The laws cannot, in fact, be enforced, and this has had unfortunate results. In other fields they are curiously restrictive, as was brought out by reference to campaigns against rabies. There is no legislation against laying poison bait, but the officers who lay it are personally financially responsible for any ensuing claim for damages. So much publicity is therefore necessary before laying bait "that even the jackals heard about it", and such campaigns have been extremely ineffective.

The conference revealed the enormous fields for research that the zoonoses hold in East Africa, and in his closing remarks the president, Mr. H. R. Binns, of the East African Veterinary Research Organization, stressed this. He called for the closest cooperation of medical and veterinary research workers and other scientists which has been so fruitful in the past, and emphasized the willingness of all institutions and organizations in East Africa to welcome visiting workers from other countries who wish to help in the solution of East Africa's many problems.

J. N. P. Davies

\section{OBITUARIES}

\section{Prof. A. O. Rankine, O.B.E., F.R.S.}

THE death, on January 20, of Alexander Oliver Rankine at the age of seventy-four removes a much respected figure from scientific circles in London, especially those connected with applied physics. $\mathrm{He}$ played a leading part in the dovelopment of important branches of that subject, including optics and geophysics, not only in their technical aspects but also in connexion with the relevant organizations, both academic and professional. In later years he gave much devoted service to the Royal Institution. $\mathrm{He}$ was a frequent lecturer there, and was honorary secretary during 1945-52.

Born in 1881, he was the son of the Rev. John Rankine, of Guildford, a Baptist minister, and started his education at the Board school at the age of four years. Later on, he attended Guildford Grammar School, whence he won a county major scholarship to University College, London, and graduated with first-class honours in physics in 1904. He was awarded the D.Sc. degree in 1910 for his published work, mostly on the viscosity of gases and associated studies of the dimensions of gaseous molecules.

He held a research appointment in University College during 1904-19, except for a period in the Admiralty Experimental Station, Harwich, during 1917-18, in which he worked on a method of telephonic communication by the modulation of a beam of light. He was made O.B.E. in 1919. After the First World War he accopted the post of assistantprofessor of physics in the Imperial College of Science and Tochnology, South Kensington, being later promoted to a full professorship. His outstanding personal gifts, genorosity and organizing capacity brought him into prominence, and when Prof. F. J. Cheshire (director of the Technical Optics Department) retired in 1925, Rankine was appointed to that post, which he held until 1931, when the Optics Department became a postgraduate branch of the Physics Department under Prof. (now Sir George)
Thomson. About this time he became the last president of the Optical Society.

The great interest in optical research stimulated by the First World War had diminished, and the Optical Society lacked the resources to maintain it as an independent body. Under Rankine's guidance it was united with the Physical Society. (Perhaps the wisdom of this step was not fully apparent until some years later, when the Optical Group of the Physical Society was formed with his help and has continued increasingly to flourish.) Rankine was president of the Physical Society for the first two years after the union. He had always taken a keen interest in that Society as its honorary secretary (1923-29) and member of Council.

He was one of the founder fellows of the Institute of Physics and served on the Board in various offices, including that of honorary secretary and vicepresident during 1923-37; also during 1943-47. His tolerance and level-headed counsel made him a highly valued member of committees, and a large amount of such work fell to his share, including various tasks in connexion with Section A of the British Association, of which he was president in 1932 .

In the early nineteen-thirties, Rankine became interested in the rapidly developing subject of geophysics, and gave much help to the early development of related studies in the Imperial College. Various papers under his name on geophysical instruments were beginning to appear at the time of his election to followship of the Royal Society in 1934 . He left the Imperial College in 1937 to become the chief physicist to the Anglo-Iranian Oil Company, in which capacity he paid several visits to Persia, encountering various adventures which he would describe in his own amusing way. Between 1942 and 1945 he was seconded to the Petroleum Warfare Department, in which connexion he had much to do with the development of 'Fido'-the use for fogdispersal of petroleum vapour burners flanking landing strips on air-fields. A visitor to Earl's Court on a wintry day might find Rankine and his assistants 